\title{
Oil-Water Adsorptive Properties of Chemically Treated Sugarcane Bagasse
}

\author{
Handojo Djati Utomo ${ }^{1}$, Phoon Ru Yi ${ }^{1}$, Shen Zhonghuan ${ }^{1}$, Ng Li Hui ${ }^{1}$ \& Lim Zheng Bang ${ }^{2}$ \\ ${ }^{1}$ School of Architecture and the Built Environment (ABE), Civil Engineering Div., Singapore Polytechnic, 500 \\ Dover Road, Singapore \\ ${ }^{2}$ Advanced Material Technology Centre, Technology Development Office, Singapore Polytechnic, 500 Dover \\ Road, Singapore \\ Correspondence: Handojo Djati Utomo, Division of Civil Engineering, School of Architecture and the Built \\ Environment, Singapore Polytechnic, 500 Dover Road, Singapore. Email: han@sp.edu.sg
}

Received: November 15, 2015 Accepted: November 27, 2015 Online Published: January 7, 2016

doi:10.5539/enrr.v6n1p35 URL: http://dx.doi.org/10.5539/enrr.v6n1p35

\begin{abstract}
Among the contaminants plaguing our waters today, oil remains one of the most pervasive and challenging contaminant to remove. Oil pollution occurs not only through factory discharge, but also by accident spills from the fuel of the vehicle or the transportation of oil. Sugarcane bagasse (SB) is an abundant agricultural by-product containing almost half of cellulose and one quarter of lignin. After chemical treatments SB can be modified their hydrophobicity leading to improve its oil adsorptive properties. In a column experiment containing $1 \mathrm{~g}$ of SB, oil was able to be adsorbed from oil and water mixture by, from the highest to the lowest uptake, AASB, ASSB, NSB, SSB and BSB with the average oil adsorption capacity of $13.0 \mathrm{~mL} / \mathrm{g}, 11.25 \mathrm{~mL} / \mathrm{g}, 10.50 \mathrm{~mL} / \mathrm{g}, 9.0 \mathrm{~mL} / \mathrm{g}$ and 8.75 $\mathrm{mL} / \mathrm{g}$ respectively. The results were concurrently meeting the result of material characterisation using FTIR, where acetic acid treated SB (AASB) consists of high lignin leading to high hydrophobicity. On the other hand, BSB showed the lowest oil adsorption capacity and more hydrophilic due to the lowest amount of lignin present in SB. The result showed a potential use of natural material of SBs with high lignin content to tackle oil spill in water environment.
\end{abstract}

Keywords: cellulose, hydrophobicity, lignin, oil spill, sugarcane bagasse, water

\section{Introduction}

Due to increasing oil consumption, oil pollution of water has steadily increased (Hussein et al., 2009). It is a global concern as one of the main sources of water contamination is oil spills or oily waste waters. It imposes a serious damage on the environment and the economics. Oil pollute all water sources such as seas, oceans, rivers or groundwater (Behnood et al., 2013). Oil spills are cause by many factors such as discharge of crude oils from tankers, ships, offshore platforms; accidental spill in pipe lines or production process; spill of other oily waste waters such as produced water and ballast water (Behnood et al., 2013). When oil is spilled into a marine environment, it is subject to several processes including spreading, drifting, evaporation, dissolution, photolysis, biodegradation and formation of water-oil emulsions (Annunciado et al., 2005). Plants and animals will be contaminated and some will be unable to survive. In general, oil spills occur in oceans, estuaries, rivers, lakes, ponds, or on land, they can affect many living things such as plants, invertebrates, fish, birds, and mammals.

Several clean-up techniques have been used to tackle oil spillage, including use of dispersants, mechanical tools and in-situ burning of oil on water (Allen, 1998). However, those clean-up practices are not efficient enough and will post environmental effects. Conversely, adsorption is becoming more common in removing organics dissolved in water (Okiel et al., 2011) due to its promising results and lower operation cost (Abdul et al., 2012; Kavitha \& Namasivayam, 2007). Synthetic sorbents such as polypropylene have good hydrophobic and oleophilic properties as they have high oil adsorption capacity (Jarre et al., 1979), but they are unable to biodegrade (Choi \& Cloud, 1992).

In recent years, agricultural by-products are being increasingly used as oil adsorbents due to their low cost and biodegradability. They include rice husk ash (Vlaev et al., 2011), barely straw (Husseien et al., 2009) and peat-based sorbents (Cojocaru et al., 2011) as well as sugarcane bagasse (SB) from the production of cane sugar. Even though SB is produced in huge abundance every year, only a small proportion of it is reused as biofuel and pulp and paper 
products (Rowell \& Keany, 1991). SB properties can also be modified in physical, biological, chemical and photochemical processes (Tronc et al., 2006). SB mainly consists of cellulose, hemicellulose, and lignin with the average content percentages of $40 \%, 30 \%$ and $20 \%$ respectively (Sun et al., 2003). In the adsorption of oil, hydrophobicity of the adsorbent is a key factor as it is a measure of repulsion of polar substances of water and attraction of non-polar substances of oil. On the other hand, hydrophilicity is the measure of attraction of polar substances and repulsion of non-polar substances. In SB, the hydrophobic functional groups are found on lignin and the hydrophilic groups are the hydroxyl groups found on cellulose and hemicellulose. Hence, in order to improve the oil adsorption capacity of SB, pretreatment of the material can be done. Different pretreatment methods applied to SB may alter the celluose crystallinity of or selectively remove the hemicellulose and lignin in the lignocellulosic substrate. The methods include physical process such as milling (Chang \& Holtzapple, 2000; Gharpuray et al., 1983) and irradiation (Taherzadeh \& Karimi, 2008; Lafitte-Trouqué and Forster, 2002), physical-chemical methods such as using ammonia explosion (Gollapalli et al., 2002) and acids and bases (Betancur \& Pereira, 2010; Deschamps et al., 1996; Sun et al., 1995), and biological methods such as using bacteria and fungi (Kurakake et al, 2007; Srilatha et al., 1995). Acids hydrolyse hemicellulose and minor amounts of lignin (Geddes et al., 2010; Rocha et al., 2011) while bases hydrolyse hemicellulose and lignin (Zhang \& Lynd, 2004; Jackson, 1977). Acetylation is also another method used to treat lignocellulosic material where hydrophobicity of the material is increased by substituting hydrophilic hydroxyl groups with hydrophobic acetyl groups. The reaction is usually carried out by heating the material with acetic anhydride, with or without the presence of a catalyst (Rowel, 1983).

The objective of the work is to investigate an oil adsorption from SB with various chemical treaments. Characterisation of the samples was first conducted to identify crystallinity, crystallite size and presence of various functional groups. Column adsorption experiments were then conducted with the SB samples using water only and a mixture of oil and water.

\section{Methodology, Equipment and Materials}

\subsection{Pre-Treatment of SB to Prepare NSB, SSB, BSB, ASSB and AASB}

An estimated $5 \mathrm{~kg}$ of SB was collected from a hawker centre using a plastic bag. After random cleaning, approximately $30 \mathrm{~g}$ of SB was weighed using a four digits weighing balance. The samples were rinsed using tap water to ensure free from any dust or fine particles. Up to $1 \mathrm{~L}$ of deionised water was used to further clean the samples. The SB was placed on an aluminium tray and dried in an oven at $103^{\circ} \mathrm{C}$ overnight to fully remove water moisture. The SB was collected the next day and cut into smaller pieces using scissors and blenders. A uniform size of SB was stored after sieving using ASTM sieve between $2.0 \mathrm{~mm}-850 \mu \mathrm{m}$. The sieved SB was labelled as natural SB of NSB. NSB was chemically treated to prepare other SB variants of SSB, BSB, ASSB and AASB after being overnightly soaked in $0.5 \mathrm{M}$ of sodium chloride, sodium hydroxide, sulphuric acid and acetic acid solutions respectively. The morphology change of SB was investigated using FTIR. Each sample was then rinsed with $8 \mathrm{~L}$ deionised water each and dried in the oven at $103^{\circ} \mathrm{C}$ overnight. All the samples were stored in labelled containers.

\subsection{Characterisation of SB using SEM, FTIR and XRD Analytical Instruments}

The SB samples' surface was scanned using SEM (JEOL- 6400) to understand the morphology of the samples. Material characterisation was conducted using the available analytical instruments of FTIR and XRD to determine various functional groups including lignin existence, existence of cellulose and size of crystalline cellulose from NSB, SSB, BSB, ASSB and AASB samples. The dried samples were grinded and embedded in KBr pellets. IR spectra of the samples were recorded by using IRPrestige-21 FTIR spectrophotometer (Shimadzu). The spectra were recorded in the transmission band mode in the range of $4000-400 \mathrm{~cm}^{-1}$. Crystallinity of the samples was determined by X-ray diffraction using D8 ADVANCE diffractometer (Bruker). The diffraction spectrum was taken by the $\theta-2 \theta$ method. Samples were scanned from $2 \theta=10^{\circ}$ to $70^{\circ}$ with a step size of $0.02^{\circ}$. The samples' crystallinity was determined as the percentage as follows:

$$
\operatorname{CrI}=\frac{\left[I_{002}-I_{a m}\right]}{I_{002}} \times 100 \%
$$

Where, $I_{002}=$ the maximum intensity of the $(002)$ lattice diffraction $\left(2 \theta \approx 22^{\circ}\right), I_{a m}=$ the intensity at $2 \theta \approx 15-18^{\circ}$ (amorphous)

The average size of the crystallites was calculated from the Scherrer equation, which was based on the width of the diffraction patterns obtained in the X-ray reflected crystalline region. In present study, the crystallite sizes were determined by using the diffraction pattern obtained from the 002 ( $h k l)$ lattice planes of samples using the following formula: 


$$
D_{(h k l)}=\frac{K \lambda}{B_{(h k l)}} \cos \theta
$$

Where, $(h k l)=$ the lattice plane, $\mathrm{D}_{(h k l)}=$ the size of crystallite, $\mathrm{K}=$ the Scherrer constant (taken as 0.9$), \lambda=$ the $\mathrm{X}$ ray wavelength $(0.154 \mathrm{~nm}), \mathrm{B}_{(h k l)}=$ the FWHM (full width half maximum) of the measured $h k l$ reflection, $2 \theta=$ the corresponding Bragg angle (reflection angle)

\subsection{Experimental Set Up using Acrylic Column}

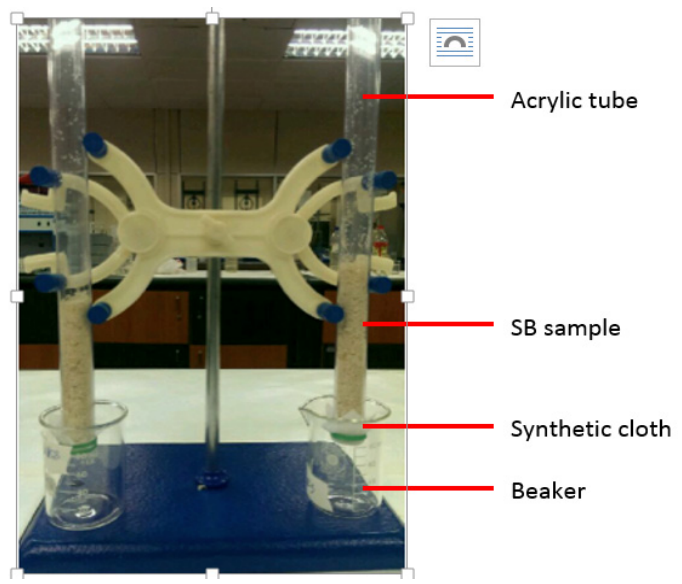

Figure 1. Experiment set up

A column experiment set up was prepared as shown in Figure 1. A fixed mass of $1.0 \mathrm{~g} \mathrm{NSB}, \mathrm{SSB}, \mathrm{BSB}, \mathrm{ASSB}$ and AASB were weighted respectively using a four digits weighing balance. Each sample was then placed into a $40 \mathrm{~cm}$ long transparent acrylic column with internal diameter of $1.8 \mathrm{~cm}$ and compacted by applying a constant weight on the sample. Two sets of experiments were conducted with the adsorbates consisting of water only and the adsorbate consisting of a mixture of used vegetable oil and water in a ratio 1:1. The total volume of $100 \mathrm{~mL}$ was used in both experiments. To prepare a fully dispersed of oil and water mixture a metal spatula was used in stirring the mixture in a $500 \mathrm{~mL}$ beaker. The adsorbate was poured into the column with SB sample and excess time was given for the mixture to pass through the column. All the filtrate was then collected and measured using $100 \mathrm{~mL}$ measuring cylinder.

\subsection{Determination of Oil and Water Adsorption of SB Samples}

The adsorption capacity of adsorbent was measured separately. Water adsorption was the expression of the volume of water that could be adsorbed after water passing through the column, either from water only or a mixture of water and oil. Oil adsorption was the expression of the volume of oil that could be adsorbed after a mixture of water and oil passing through the column. Both were expressed in $\mathrm{mL}$ of water per $\mathrm{g}$ of $\mathrm{SB}$ or $\mathrm{mL}$ of oil per $\mathrm{g}$ of $\mathrm{SB}$, in the case of the water and oil mixture used.

$$
\begin{aligned}
& \text { Water adsorption }(\mathrm{mL} / \mathrm{g})=\left[\left(\mathrm{W}_{\mathrm{i}}-\mathrm{W}_{\mathrm{f}}\right) / \mathrm{M}\right] \\
& \text { Oil adsorption }(\mathrm{mL} / \mathrm{g})=\left[\left(\mathrm{O}_{\mathrm{i}}-\mathrm{O}_{\mathrm{f}}\right) / \mathrm{M}\right]
\end{aligned}
$$

Where $\mathrm{W}_{\mathrm{i}}=$ Initial volume of water $(\mathrm{mL}), \mathrm{W}_{\mathrm{f}}=$ Final volume of water $(\mathrm{mL}), \mathrm{O}_{\mathrm{i}}=$ Initial volume of oil $(\mathrm{mL}), \mathrm{O}_{\mathrm{f}}=$ Final volume of oil (mL), M = Mass of SB in the column $(\mathrm{g})$

\section{Results and Analysis}

\subsection{SB Characterisation using SEM, XRD and FTIR}

Figure 2(a) shows physical appearance of various SB samples with the related SEM surface images shown in Figure 2(b) to 2(f). 


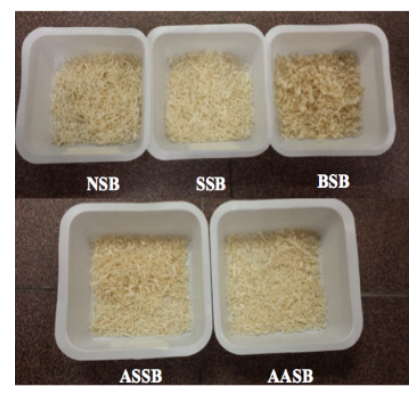

Figure 2(a). Physical appearance of SB samples
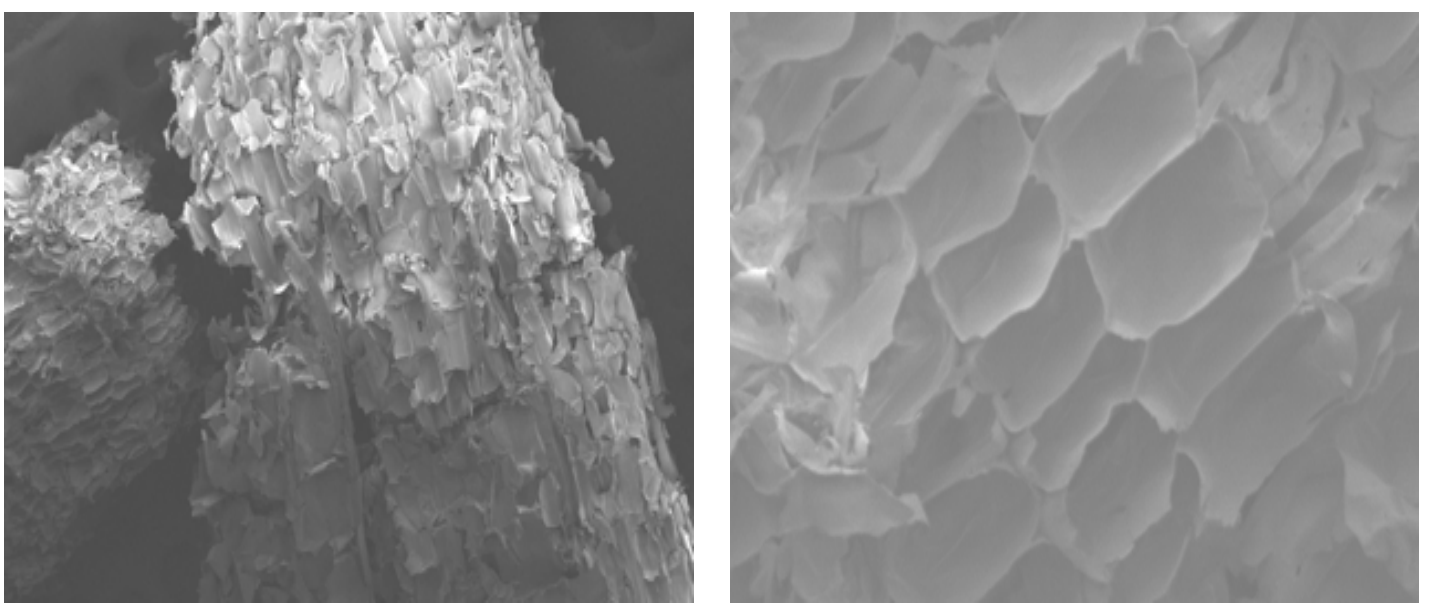

Figure 2(b). SEM image of NSB sample magnified 25 times (left) and 200 times (right)
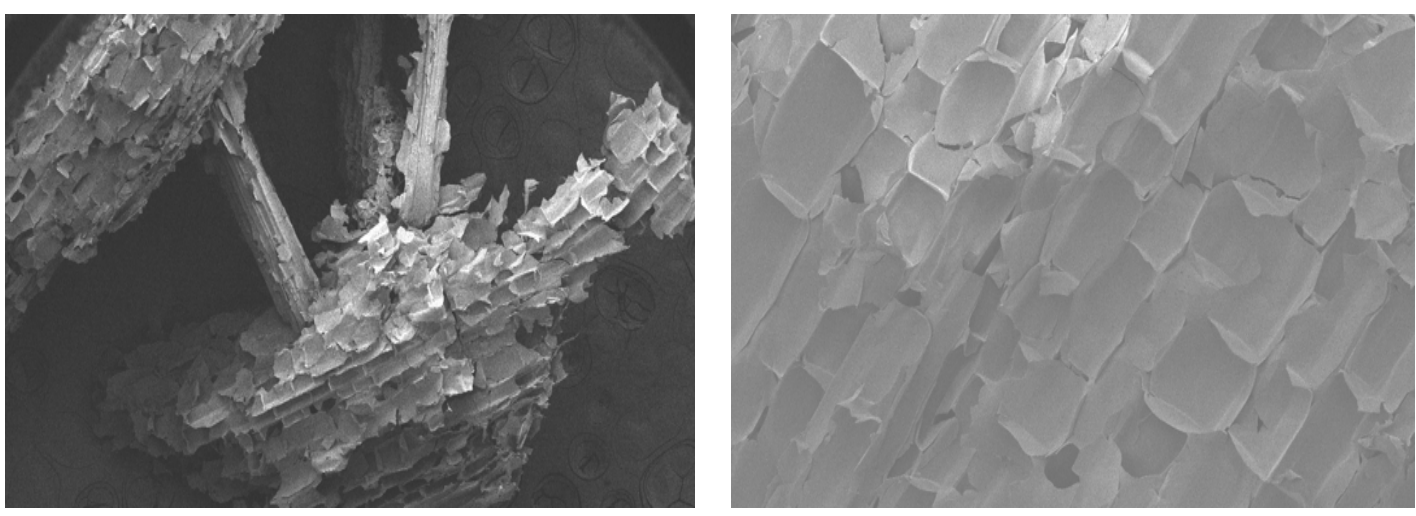

Figure 2(c). SEM image of SSB sample magnified 25 times (left) and 100 times (right)
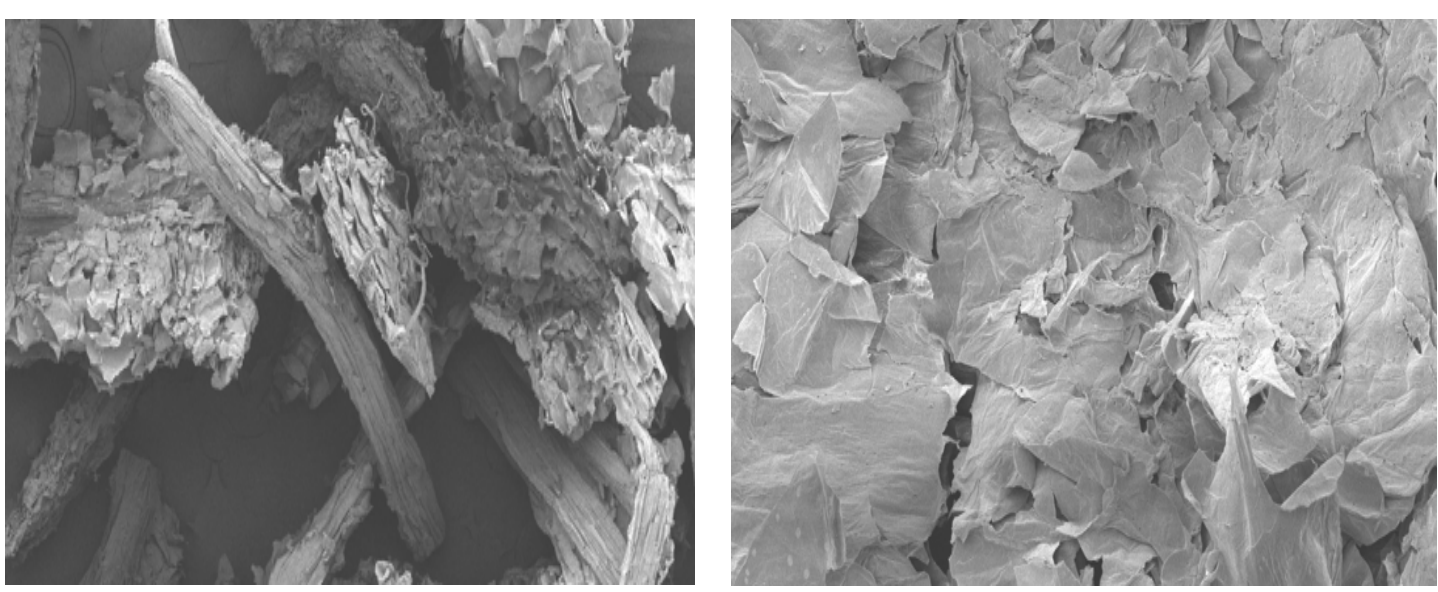

Figure 2(d). SEM image of BSB sample magnified 25 times (left) and 300 times (right) 

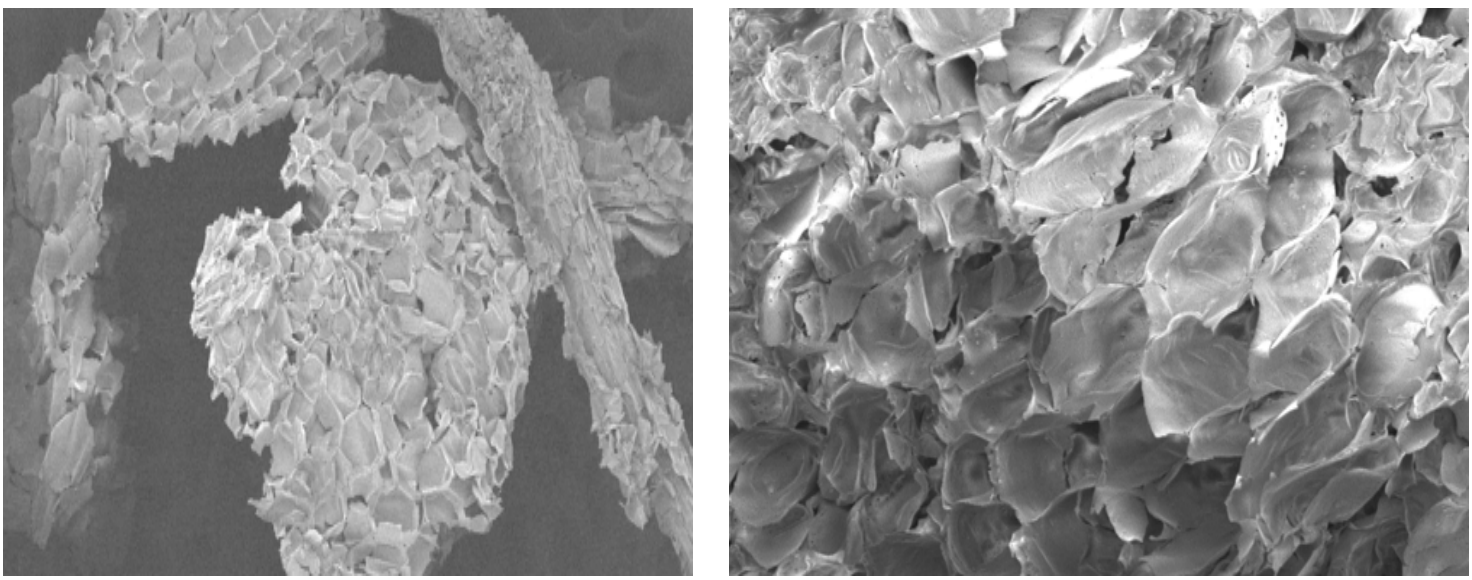

Figure 2(e). SEM image of ASSB sample magnified 25 times (left) and 200 times (right)
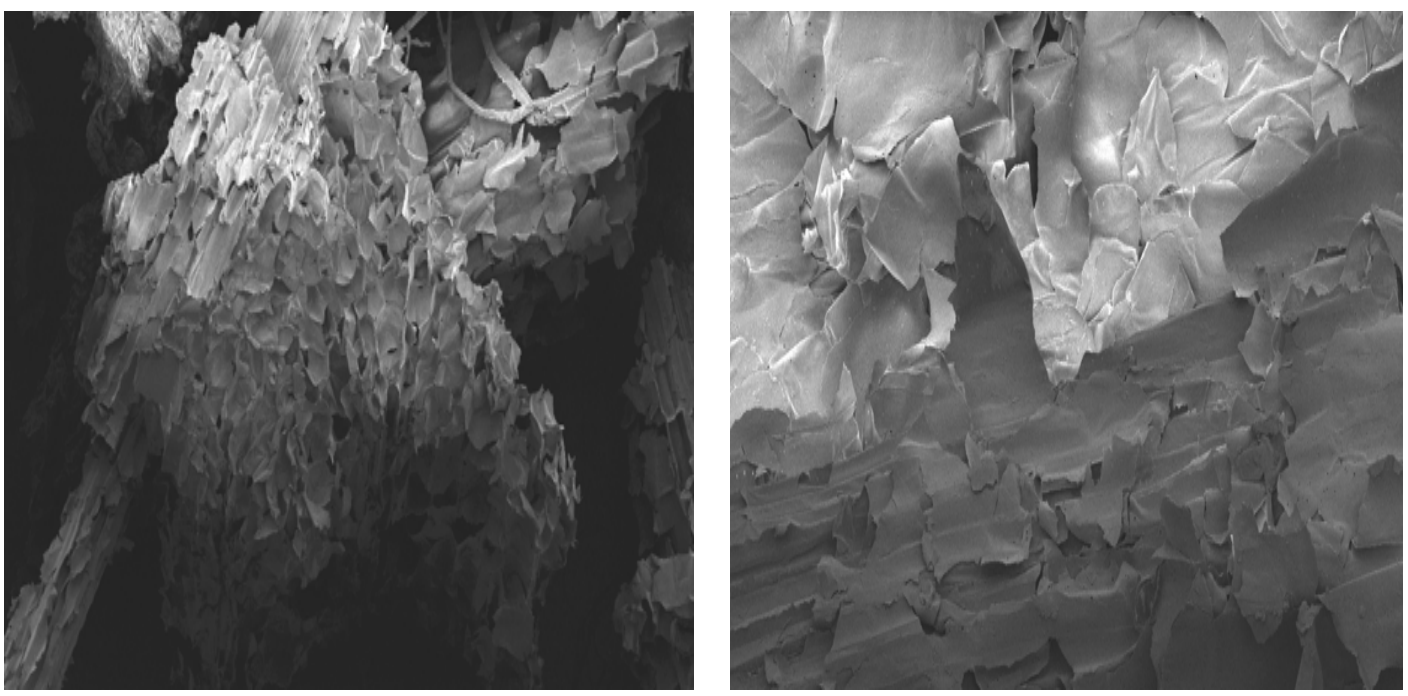

Figure 2(f). SEM image of AASB sample magnified 25 times (left) and 140 times

Figure 2(a) showed that all the SB samples have similar physical appearances except for BSB which was darker yellow and has a greater tendency to stick to each other. BSB also had a higher density compared to the rest of the samples. The surface texture and shape of each SB sample could be differentiated using SEM. Figure 2(b) showed that NSB is flaky and rough surface with regular rectangular honeycomb structure of cellulose in its surface as magnified 25 to 220 times. Similar surface characteristic was also shown in Figure 2(c), after NSB experiencing sodium chloride treatment. Square shapes and more irregular honeycomb pattern of cellulose was shown in Figure 2(e), after experiencing sulphuric acid treatment. Figure 2(d) and 2(f) showed that SB surface has rougher surface due to oxidation process of sodium hydroxide and acetic acid. More irregular pattern and collapsing honeycomb cellulose structure could be seen too. Chung et al (2011) measured the BET surface area of untreated SB of 0.9 $\mathrm{m}^{2} / \mathrm{g}$ could be improved up to $60 \%$ after acetic acid treatment.

Table 1. Density, crystallinity and crystallite size of SB samples

\begin{tabular}{cccc}
\hline Sample & Density (g/cm $\left.\mathbf{c m}^{\mathbf{3}}\right)$ & Crystallinity (\%) & Crystallite size (nm) \\
\hline NSB & 0.0342 & 29.038 & 3.300 \\
SSB & 0.0342 & 37.014 & 3.321 \\
BSB & 0.0513 & 65.329 & 3.192 \\
ASSB & 0.0342 & 54.848 & 3.100 \\
AASB & 0.0342 & 59.359 & 3.069 \\
\hline
\end{tabular}




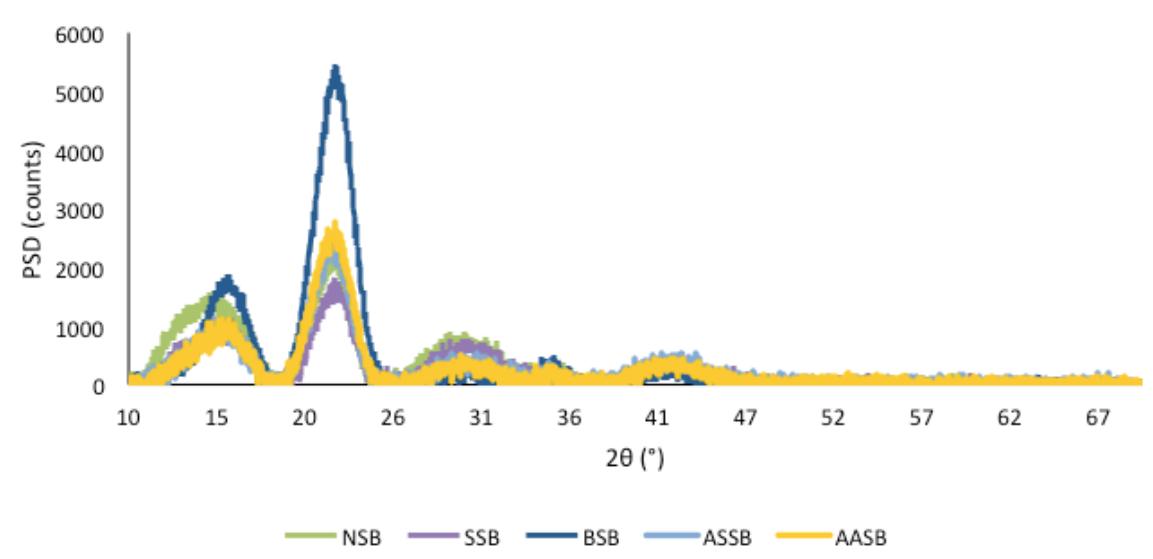

Figure 3. XRD spectra of SB samples

With reference to the XRD spectra of SB samples in Figure 3, the diffraction spectrum at $15-18^{\circ}$ and $22^{\circ}$ represent cellulose in the amorphous and crystalline forms respectively. As expected the simple pre-treatments of SB samples was not expected to produce nano crystallite sizes but to change the hydrophobicity of SB samples. With the removal of lignin by $\mathrm{NaOH}$ base, the plant cell walls in BSB lose their structural integrity and cause the cellulose to collapse into an amorphous form as it was clearly shown in SEM scan in Figure 2(d). BSB had a much higher crystallinity as compared to the rest of the SB samples. In Table 1, BSB showed the highest crystallinity of cellulose $\operatorname{CrI}(1)$, followed by AASB, ASSB, SSB and NSB. The high density of BSB is in agreement with its high crystallinity. According to the Scherrer's equation (2), the order of crystallite sizes were shown as NSB, SSB, BSB, ASSB and ASSB. The effect of crystallite size of celllulose on oil adsorption capacity for the SB samples may be partly co-related.

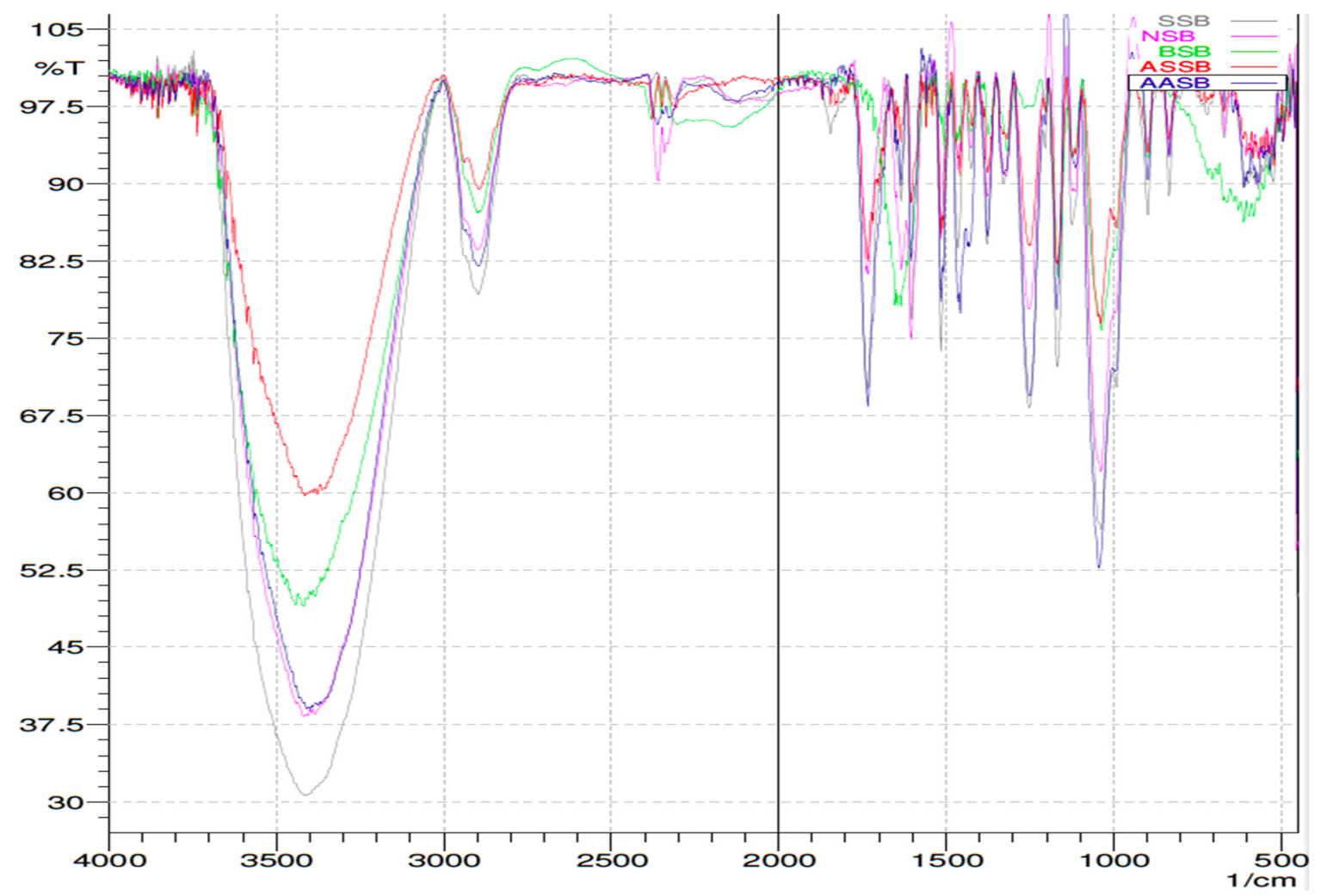

Figure 4. FTIR spectra of SB samples 
Figure 4 showed FTIR spectra of SB samples with the bands associated with the hydroxyl O-H group, lignin and acetyl group. The bands at $3400 \mathrm{~cm}^{-1}$ and $2910 \mathrm{~cm}^{-1}$ are assigned to $\mathrm{O}-\mathrm{H}$ stretching and $\mathrm{C}-\mathrm{H}$ stretching respectively in all five SB samples. For O-H stretching, SSB has the highest intensity, followed by similar values from NSB and AASB. The second lowest intensity is BSB and the lowest intensity is ASSB. The O-H trend for BSB and ASSB could have been due to the partial and significant removal of hemicellulose respectively. The lower removal of O-H groups in AASB compared to ASSB could have been due to the fact that acetic acid is a weaker acid than sulphuric acid. For $1600 \mathrm{~cm}^{-1}$ and $1510 \mathrm{~cm}^{-1}$, they represent the aromatic skeletal vibrations. Generally, SSB shows the highest intensity of lignin, followed by AASB, NSB, ASSB and finally BSB. For acetyl group, $1750 \mathrm{~cm}^{-1}$ represents the $\mathrm{C}=\mathrm{O}$ bond, $1380 \mathrm{~cm}^{-1}$ represents the $-\mathrm{C}-\mathrm{CH}_{3}-$ bond and $1240 \mathrm{~cm}^{-1}$ represents the $-\mathrm{C}-\mathrm{O}-$ bond. For all the acetyl associated bands, AASB has one of the highest intensities. Hence, it is possible that some acetylation could have taken place. Band at around $1040-1060 \mathrm{~cm}^{-1}$ is assigned to $\mathrm{C}-\mathrm{O}$ (primary alcohol) which the AASB is having the lowest intensity at this band.

\subsection{Water adsorption onto $S B$ samples}

Adsorption of water measures the hydrophilicity of the material. The higher the water adsorption, the more hydrophilic the material is. Table 2 showed the results of the water adsorption experiments indicating that NSB is the most hydrophilic, followed by SSB, AASB, ASSB and BSB. A duplicate of volume measurements using two different batches of SB column were conducted as shown as V1 and V2 in Table 2.

Table 2. Adsorption of water onto $1 \mathrm{~g}$ of NSB, SSB, BSB, ASSB and AASB

\begin{tabular}{|c|c|c|c|c|c|}
\hline \multirow{2}{*}{ SB types } & \multirow{2}{*}{ Initial volume $(\mathrm{mL})$} & \multicolumn{3}{|c|}{ Water filtrate volume $(\mathrm{mL})$} & \multirow{2}{*}{$\begin{array}{l}\text { Average water } \\
\text { adsorption } \\
(\mathrm{mL} / \mathrm{g})\end{array}$} \\
\hline & & V1 & $\mathrm{V} 2$ & Average V & \\
\hline NSB & & 84.0 & 85.0 & 84.5 & 15.5 \\
\hline SSB & & 84.5 & 86.0 & 85.3 & 14.7 \\
\hline BSB & 100 & 88.0 & 89.0 & 88.5 & 11.5 \\
\hline ASSB & & 85.0 & 88.0 & 86.5 & 13.5 \\
\hline AASB & & 87.0 & 85.0 & 86.0 & 14.0 \\
\hline
\end{tabular}

These results are generally in line with the intensity of O-H groups in different SB types, with NSB and SSB having the greatest amount of O-H and ASSB and BSB having the least amount of O-H.

\subsection{Adsorption of Oil and Water Mixture onto SB Samples}

The average water adsorption from adsorption of oil and water mixture (Table 3 ) shows a similar trend as that of adsorption of water alone in Section 3.2. Adsorption of oil measures the hydrophobicity of the material. The higher the oil adsorption, the more hydrophobic the material is. For oil adsorption, AASB shows the greatest hydrophobicity, followed by ASSB, NSB, SSB and BSB. This is generally in agreement with the material characterisation where AASB has one of the highest lignin and acetyl group content while BSB has the lowest lignin content. AASB may be the most hydrophobic sample among the SB samples. A duplicate of volume measurements using two different batches of SB column were conducted as shown as V1 and V2 in Table 3.

Table 3. Oil adsorption onto $1 \mathrm{~g}$ of NSB, SSB, BSB, ASSB and AASB in the mixture of oil and water

\begin{tabular}{|c|c|c|c|c|c|c|c|c|c|}
\hline \multirow{2}{*}{$\begin{array}{l}\text { SB } \\
\text { types }\end{array}$} & \multirow{2}{*}{$\begin{array}{c}\text { Water } \\
\text { and } \\
\text { oil } \\
\text { mixture } \\
(\mathrm{mL})\end{array}$} & \multicolumn{3}{|c|}{$\begin{array}{l}\text { Water filtrate volume } \\
\qquad(\mathrm{mL})\end{array}$} & \multicolumn{3}{|c|}{$\begin{array}{l}\text { Oil filtrate volume } \\
(\mathrm{mL})\end{array}$} & \multirow{2}{*}{$\begin{array}{c}\text { Avg. water } \\
\text { adsorption } \\
(\mathrm{mL} / \mathrm{g})\end{array}$} & \multirow{2}{*}{$\begin{array}{l}\text { Avg. oil } \\
\text { adsorption } \\
(\mathrm{mL} / \mathrm{g})\end{array}$} \\
\hline & & V1 & V2 & $\begin{array}{l}\text { Avg } \\
\text { vol }\end{array}$ & V1 & V2 & $\begin{array}{l}\text { Avg } \\
\text { vol }\end{array}$ & & \\
\hline NSB & \multirow{5}{*}{100} & 40.0 & 39.0 & 39.5 & 40.0 & 39.0 & 39.5 & 10.50 & 10.50 \\
\hline SSB & & 37.0 & 38.0 & 37.5 & 41.0 & 41.0 & 41.0 & 12.5 & 9.0 \\
\hline BSB & & 41.5 & 42.0 & 41.75 & 41.5 & 41.0 & 41.25 & 8.25 & 8.75 \\
\hline ASSB & & 39.5 & 39.0 & 39.25 & 38.5 & 39.0 & 38.75 & 10.75 & 11.25 \\
\hline AASB & & 40.0 & 43.0 & 41.5 & 38.0 & 36.0 & 37.0 & 8.5 & 13.0 \\
\hline
\end{tabular}




\section{Conclusion}

The presence of hydrophilic hydroxyl groups and hydrophobic lignin in all SB samples has enabled them to adsorb water and oil. However, a greater amount of hydroxyl groups in NSB and SSB have resulted in higher water adsorption while a greater amount of lignin groups in AASB have resulted in higher oil adsorption. The result of column experiment indicated that only AASB may be identified as the most hydrophobic sample and BSB the least hydrophobic sample. FTIR analysis showed that simple chemical treatment of soaking SB in acetic acid overnight was able to substitute some hydroxyl groups with acetyl groups. Although ASSB has the second highest oil adsorption after AASB, use of sulphuric acid for chemical treatment may be more environmentally unfriendly than acetic acid. Hence, AASB is the most suitable material for oil adsorption in aqueous environments.

\section{Acknowledgement}

This project is supported by Singapore Polytechnic TIEFA Fund with Vote Numbers 11-30012-36-R185/ 1111000-36-R185/11-27801-36-R185.

\section{References}

Allen, A. A. (1988). 'In-situ burning, Alaska Arctic offshore oil spill response technology. NIST, 762, 11-14.

Annunciado, T. R., Sydenstricker, T. H. D., \& Amico, S. C. (2005). Experimental investigation of various vegetable fibers as sorbent materials for oil spills. Marine Pollution Bulletin, 50(11), 1340-1346. http://dx.doi.org/10.1016/j.marpolbul.2005.04.043

Begum, H. A., \& Mahbub, M. K. B. (2013). Effectiveness of Carboxymethyl Cellulose for the Removal of Methylene Blue from Aqueous Solution. Dhaka University Journal of Science, 61(2), 193-198.

Behnood, R., Anvaripour, B., Jaafarzade Haghighi Fard, N., \& Farasati, M. (2013). Petroleum hydrocarbons adsorption from aqueous solution by raw sugarcane bagasse. Int J Emerg Sci Eng, 1(6), 2319-6378.

Chang, V. S., \& Holtzapple, M. T. (2000, January). Fundamental factors affecting biomass enzymatic reactivity. In Twenty-First Symposium on Biotechnology for Fuels and Chemicals (pp. 5-37). Humana Press. http://dx.doi.org/10.1385/ABAB:84-86:1-9:5

Choi, H. M., \& Cloud, R. M. (1992). 'Natural Sorbents in Oil Spill Clean-up. Environmental Science and Technology, 26, 772- 776. http://dx.doi.org/10.1021/es00028a016

Chung, S., Suidan, M. T., \& Venosa, A. D. (2011). Partially acetylated sugarcane bagasse for wicking oil from contaminated wetlands. U.S. Environmental Protection Agency Papers, Paper 118.

Chung, S., Suidan, M. T., \& Venosa, A. D. (2011). Partially acetylated sugarcane bagasse for wicking oil from contaminated wetlands. Chemical Engineering \& Technology, 34(12), 1989-1996. http://dx.doi.org/10.1007/BF02941697

Cojocaru, C., Macoveanu, M., \& Cretescu, I. (2011). Peat-based sorbents for the removal of oil spills from water surface: Application of artificial neural network modeling. Colloids and Surfaces A: Physicochemical and Engineering Aspects, 384(1), 675-684. http://dx.doi.org/10.1016/j.colsurfa.2011.05.036

de Moraes Rocha, G. J., Martin, C., Soares, I. B., Maior, A. M. S., Baudel, H. M., \& De Abreu, C. A. M. (2011). Dilute mixed-acid pretreatment of sugarcane bagasse for ethanol production. biomass and bioenergy, 35(1), 663-670. http://dx.doi.org/10.1016/j.biombioe.2010.10.018

Geddes, C. C., Peterson, J. J., Roslander, C., Zacchi, G., Mullinnix, M. T., Shanmugam, K. T., \& Ingram, L. O. (2010). Optimizing the saccharification of sugar cane bagasse using dilute phosphoric acid followed by fungal cellulases. Bioresource technology, 101(6), 1851-1857. http://dx.doi.org/10.1016/j.biortech.2009.09.070

Gharpuray, M. M., Lee, Y. H., \& Fan, L. T. (1983). Structural modification of lignocellulosics by pretreatments to enhance enzymatic hydrolysis. Biotechnology and bioengineering, 25(1), 157-172. http://dx.doi.org/10.1002/bit.260250113

Hussein, M., Amer, A. A., Sawsan, I., \& Meric, S. (2009). Oil spill sorption using carbonized pith bagasse. Application of carbonized pith bagasse as loose fiber. Global nest. The international journal, 11(4), 440-448.

Jackson, M. G. (1977). Review Article: The Alkali Treatment Of Straws'. Anim Feed Sci Technol, 2, 105-130. http://dx.doi.org/10.1016/0377-8401(77)90013-X

Jarre, W., Marx, M., \& Wurmb, R. (1979). Polyurethanschäume mit hohem ölabsorptionsvermögen. Die Angewandte Makromolekulare Chemie, 78(1), 67-74. http://dx.doi.org/10.1002/apmc.1979.050780104 
Kavitha, D., \& Namasivayam, C. (2007). Recycling Coir Path, An Agricultural Solid Waste, For The Removal Of $\begin{array}{lllll}\text { Procion Orange From Wastewater. Dyes Pigments, } & \text { 74, 237. }\end{array}$ http://dx.doi.org/10.1016/j.dyepig.2006.01.040

Kurakake, M., Ide, N., \& Komaki, T. (2007) . Biological Pretreatment With Two Bacterial Strains For Enzymatic Hydrolysis Of Office Paper. Curr Microbiol, 54, 424-428. http://dx.doi.org/10.1007/s00284-006-0568-6

Lafitte-Trouque, S., \& Forster, C. F. (2002). The use of ultrasound and $\gamma$-irradiation as pre-treatments for the anaerobic digestion of waste activated sludge at mesophilic and thermophilic temperatures. Bioresource Technology, 84(2), 113-118. http://dx.doi.org/10.1016/S0960-8524(02)00038-X

M. Husseien, A. A. Amer, A. El-Maghraby, N. A.Taha, 2009. Availability Of Barley Straw Application On Oil Spill Clean Up. International Journal of Environmental Science and Technology, 6, 123-130. http://dx.doi.org/10.1007/BF03326066

Okiel, K., El-Sayed, M., \& El-Kady, M. Y. (2011). Treatment of oil-water emulsions by adsorption onto activated carbon, bentonite and deposited carbon. Egyptian Journal of Petroleum, 20(2), 9-15.

Rowell, R. M. (1983). Chemical modification of wood. In For. Prod. Abstr (Vol. 6, No. 1983, pp. 363-82).

Rowell, R. M., \& Keany, F. M. (1991). Fiberboards made from acetylated bagasse fiber. Wood and fiber science, 23(1), 15-22.

Srilatha, H. R., Nand, K., Babu, K. S., \& Madhukara, K. (1995). Fungal pretreatment of orange processing waste by solid-state fermentation for improved production of methane. Process Biochemistry, 30(4), 327-331. http://dx.doi.org/10.1016/0032-9592(95)87041-5

Sun, R., Lawther, J. M., \& Banks, W. B. (1995). Influence of alkaline pre-treatments on the cell wall components of wheat straw. Industrial crops and products, 4(2), 127-145. http://dx.doi.org/10.1016/09266690(95)00025-8

Sun, X. F., Sun, R. C., \& Sun, J. X. (2003). A convenient acetylation of sugarcane bagasse using NBS as a catalyst for the preparation of oil sorption-active materials. Journal of Materials Science, 38(19), 3915-3923. http://dx.doi.org/10.1023/A:1026189911651

Taherzadeh, M. J., \& Karimi, K. (2008). Pretreatment Of Lignocellulosic Wastes To Improve Ethanol And Biogas Production: A Review. Int J Mol Sci, 9, 1621-1651. http://dx.doi.org/10.3390/ijms9091621

Tronc, E., Hernandez-Escobar, C. A., Ibarra-Gomez, R., Estrada-Monje, A., Navarrete-Bolanos, J., \& ZaragozaContreras, E. A. (2007). Blue agave fiber esterification for the reinforcement of thermoplastic composites. Carbohydrate Polymers, 67(2), 245-255. http://dx.doi.org/10.1016/j.carbpol.2006.05.027

Vargas Betancur, G. J., \& Pereira Jr, N. (2010). Sugar cane bagasse as feedstock for second generation ethanol production: Part I: Diluted acid pretreatment optimization. Electronic Journal of Biotechnology, 13(3), 1011.

Vlaev, L., Petkov, P., Dimitrov, A., \& Genieva, S. (2011). Cleanup of water polluted with crude oil or diesel fuel using rice husks ash. Journal of the Taiwan Institute of Chemical Engineers, 42(6), 957-964. http://dx.doi.org/10.1016/j.jtice.2011.04.004

Wild Life and Oil Spills. (2014). In EPA, United States Environmental Protection Agency. Retrieved July 20, 2014, from http://www.epa.gov/osweroe1/docs/oil/edu/oilspill_book/chap5.pdf

Zhang, Y. H. P., \& Lynd, L. R. (2004). Toward an aggregated understanding of enzymatic hydrolysis of cellulose: noncomplexed cellulase systems. Biotechnology and bioengineering, 88(7), 797-824. http://dx.doi.org/10.1002/bit.20282

\section{Copyrights}

Copyright for this article is retained by the author(s), with first publication rights granted to the journal.

This is an open-access article distributed under the terms and conditions of the Creative Commons Attribution license (http://creativecommons.org/licenses/by/3.0/). 